\title{
End Times According to Stanley Cavell
}

\section{[a review essay of Larry Jackson's Skepticism} and Redemption: The Political Enactments of

\section{Stanley Cavell]}

AMIR KHAN

Unintelligibility. Madness. Death. These are strange and ominous words to lead any essay, but the words themselves are not so strange to philosophy, and certainly not to anyone with an ear for Stanley Cavell's voice. Then certainly philosophy uses them in a strange way, or, say, in unconventional ways. To assume these words mean what they "ordinarily" do (when reading Cavell) is to put on a presumption of drama that is not only uncalled for, but romantically irritating. When Cavell says unintelligibility, he doesn't really mean unintelligible; when he says madness, he cannot possibly mean madness; and when he says death, he cannot possibly mean death. So what is with philosophy's or Cavell's insistence on using these words outside of their ordinary habitat, particularly when Cavell is so obviously sympathetic to the Wittgensteinian plea to bring language back from holiday?

Does Cavell wish to add extraordinary supplements to words like unintelligibility, madness, and death, or does he wish for us to read and understand these words in precisely their ordinary and natural setting? If the latter, how can this be?

Put as bluntly and non-romantically as possible: no one would risk unintelligibility (i.e., actually speaking in tongues) for the sake of philosophy. No one would risk madness or losing one's grip on reality for philosophy. No one would risk death, or physical extinction, to do philosophy. In their ordinary contexts, these are very bad things indeed, so why should philosophy, in explicitly seeking to avoid charges of romanticism, insist on such macabre terms in the first place? But surely a title with the word redemption in it cannot help but echo romantic sentiment. But does Jackson 
(via Cavell) provide too much or too little? In the end, that is, is Cavell's philosophy hopeful or baleful? I can only offer the following: on my reading, upon my understanding of Jackson's masterful take on the words and work of Stanley Cavell, one comes away feeling that Cavell holds out on the promise of philosophy, which means that in the present, to do philosophy like Cavell, or to see the world as he sees it is to commit to a dark vision indeed. Jackson renders Cavell's work thus: the world is bad, in bad shape, and in no way ready for philosophy-which is a strange, unnatural, and extraordinary rendering of "redemption" as well.

Reader, let me be clear: Larry Jackson's Skepticism and Redemption is a tour de force. Despite its remarkable ability to provide suitable signposts for us to make our way through the vast (and truly, I mean vast) expanse of Cavell's thought and thinking, Jackson's book leaves no room, as far as I can tell, for any type of emancipatory politics, or politics of solidarity-the hope for which is the driving engine of the piece, particularly for those (like myself) who have managed to internalize disparate realms of Cavell's thought disparately. Put another way: this book is for those who have compartmentalized Cavell's thinking (on film, on ordinary language, on Shakespeare), who have avoided "manipular" attempts to give meaning and cohesion to Cavell's thought as though to do so would be to "enact" some sort of philosophical enterprise out of Cavellian spirit. But the promise of a Cavellian politics is tantalizing, and Jackson's book reads in the manner of a philosophical caper. He takes us to the end and we are forced to follow along precisely because his title promises a politics.

Which leads to two principal ironies of the book. The first is that it cites Emerson: "But I have not found that much was gained by manipular attempts to realize the world of thought" (47), which is to say that not much is to be gained by systematizing, ontologizing, or methodologizing the world we think, as opposed to the world we inhabit. Yet this book is just such a manipular attempt aimed at the world that Cavell thinks. Part of the reason I found myself so engrossed by Jackson's essay, I think, is because it does something I had long resisted doing, something I think Cavell's work specifically uncalls for, i.e., the manipular attempt at constructing a cohesive, unified Cavellian ontology (specifically, a political one). The hope of a unified Cavellian politics, and the belief that such a thing could be achieved forced me to draw down 
some of the defences I had unknowingly put up. Make no mistake: Jackson's book, like most of Cavell's work, is so skillfully executed that one could easily (mis)construe it as dangerous, even diabolical.

If we are aware of the first irony as we read Jackson's essay, the second is apparent in hindsight only. The book itself (to which I am doing considerable disservice in fleshing out this "spoiler"), in the end, does not leave us with a politics in hand but still begging for a politics, despite its well-earned exhortation that we may not have, as of yet, earned the right to do politics at all-because even if I, or you, dear reader, have internalized the political thinking of "everyday" and "ordinary" redemptions necessary to truly enact a stance of "skepticism," it is frightfully apparent that no one else has. Part of the revolutionary potential of Cavell's writings comes in the waiting (patience, and patience) for others to come around. The Cavellian lesson brought to bear by Jackson is that if this world is not ready to own up to its own words-if this world continues, that is, to swallow the words of others in order not to see its own vulnerabilities-then the best we can accomplish as a political act is not even the direct calling out of such stances of cowardice, but the indirect expression of our own inner transformation and recognition of our countrymen's hollow thoughts and speech.

If responsibility is the definitive feature of freedom [...] then we are not free until we have set aside childish words, or rather, ceased to let words speak for us, as though they were our parents. Yes, they were here before us and we do inherit them: so too must we claim them [...]. The epic [Walden] Thoreau writes is a war over words: words he must capture by living what they mean. Only then is he responsible for what he says, only then is he free. Until the nation can speak in this way it is not free either. "In religion and politics, literality is defeated because we allow our choices to be made for us," writes Cavell. He adds, "in politics we allow ourselves to say, e.g., that a man is a fugitive who is merely running from enslavement. That is an attempted choice of meaning, not an autonomous choice of words." [...] What does it mean, then, to say [...] that politics requires the renunciation of our cannibalism? It means no longer swallowing the words of others. (214-215) 
What the nation acts, in its understanding of fugitives and slaves, is not, at least not necessarily, the world I think. To claim one's language is to have the courage to think for oneself. It may be obvious enough nowadays that a slave running from enslavement is not a fugitive. But what exactly is a fugitive today? Is an immigrant a fugitive? What makes an immigrant illegal?

But these are heady questions. And while Cavell in Jackson's hands is deeply troubled by America's sins (slavery and Vietnam), I don't think Jackson ever promised heady answers to be articulated elsewhere (say, in our legislatures or at executive board meetings). What Jackson did promise, or what we are at the very least tempted with, is the possibility that our ordinary and everyday transcendences of injustice might result in some version of collective emancipatory politics not as yet-to-be or elsewhere, but here, now, in the present: a present politics of individual, everyday, ordinary redemptions somehow collectivized and carrying, of course, a bona fide Cavellian stamp of approval.

Cavell's entire philosophical project thus begins as the removal of the tragic curses of war and racism that plagued America in the 1960s ... "We have, as tragic figures do, to go back to beginnings," writes Cavell, "either to un-do or to be undone, or to do again the thing which has caused tragedy, as though at some point in the past history is stuck, and time marks time there waiting to be released." It is the task of releasing the time, of setting it right by undoing America's curses, that leads Cavell [...] to Thoreau's Walden, a book also written in response to an imperialist war (in Mexico) and the evils of racism (as slavery); a book also dedicated to claiming a new existence for America. (163)

Perhaps America's tragedy, its inability to address the curses which have plagued its existence, has been collectivized. Indeed, Jackson's discussion on what constitutes "public" as opposed to "private" tragedy is entirely useful: modern politics became "tragic" the moment the idea of political "consent" moved away from the church or state into the realm of (secular) politics. The citizen can no longer take for granted manipular ontologies ratified by either the church or state as constituting the real. What instead marks the real is our own voicing of consent; our consent-to-be-offered, 
sincerely, genuinely, is now the only authentic political act. In a sense, the modern "performance" of political consent means not that we must shun masks but learn to embrace the mask proper to us. We must decide which religion suits us, which government suits us and in so doing, we are guaranteed to face disappointment because we will never find the "true" religion (true to me, or to us), nor will we ever find the "true" government (true to me, or to us) in the world we inhabit. In the end we do not really express consent at all, but dis-consent-i.e., our dissatisfaction with words and the world as they stand. Paradoxically, only by so doing are we expressing any sort of meaningful consent of any kind (which is, at the very least, a desire to be heard), albeit one that cannot be ratified by the state apparatus at all, which, of course, begs the question: "Why go on repeating yourself if what you say goes unheeded?" (241)

If our lives do in fact rest on theater nowadays, as Cavell claims in his reading of Hamlet, then redemption will not mean the end of acting, the but the end of tired roles and worn out scripts. It will mean, therefore, "to act without performing." And if theatricality is akin to the fantasy of a private language, in which I have perfect control over what I express, then presentness means abandoning "the wish for total intelligibility." It means assuming the risk of becoming unintelligible in entering the visible, audible [i.e. public] world I share with others; presentness is "the capacity to exist for others, to acknowledge and accept the limitedness of others' views of oneself." When I am as yet unknown and thus unintelligible to others, all I can do is enact my existence once more. (153)

The steps are tricky. First, one must decry or denounce any public ratification of one's words and world. Second, one must be willing to "wage war" with one's (own) words in order to examine what they really mean for society and for oneself. Third, one must not then renounce words altogether as inadequate, but find ways and steps to ratify one's disappointment with them publicly, which may be to offer a rebuke, or may be, indeed, to offer one's rebuke in silence as though by refusing to take up and use words so cavalierly, one is holding out on the promise of words, or, at the very le- 
ast, the hopes for emancipation and justice that seem to derive from the fact that we, as human beings, are creatures fated to use words to express our desires.

So the true political question becomes not, "How do we achieve perfect justice?” or, “Are we on our way to achieving perfect justice?”, but rather, "Is the justice we have now good enough?" And if it is not, we do not move forward couched cozily within some prearranged teleological unfolding that guarantees some future emancipation (the standard understanding of "redemption")-in a sense, prescribing the way forward (championing what are, in effect, tired old oppressions, whether of "freedom," "justice," "equality," or more degrees of it) but precisely backwards, to break down the ways in which we use and understand these phrases in the first place as if in our counterfeit understanding of these words lies the true source of unfreedom, injustice, and inequality.

The desire or need for spiritual self-examination requires retiring, for some measure of time at least, from the human community of shared language. True political consent can only be formed when one is given time and space to contemplate one's own allegiance to the world and words which one finds oneself in by matter of sheer contingency. The withdrawal from society, the withdrawal of consent, the desire not to speak, however temporary, are all essential in ensuring one has a public voice at all.

[Cavell's] concept of redemption thus resembles the demand that occupies the place of the cogito in Marx: "I am nothing and should be everything," only, in this iteration the actor is no longer the Proletariat. It is America. (15)

Later, Jackson adds:

Being outside the order of law means that I risk unintelligibility, that I suffer accusations of childishness, madness, illness, criminality, or worse. I have no authority, no appeal, no claim to standing beyond a voice or the silent staging of my desire and my humanity [...]. I feel wronged [or, perhaps, feel others to have been wronged] and wish to establish a new standard, surpassing that of my society, for measuring human justice. Risking unintelligibility in this realm 
does not mean that I have given up on making myself understood [...]. On the contrary, I refuse despair by persisting in my attempt to achieve intelligibility outside of the available conditions for political conversation, driven by the feeling that action and intelligibility are impossible within the order of law ... I am, as an exile, no one, which is precisely why I can speak for all, why, at that moment, "I stand for humanity." What I called Marx's cogito becomes this for Cavell: I am no one, and I speak as everyone. (25-26)

Jackson has not the proletariat as nothing, but America. America is in exile, is an immigrant, stemming from its original desire to break away from the community of European nations to found its own Republic. By virtue of claiming its independence in 1776, America took on a massive political risk of unintelligibility; it started from nothing in order to one day speak for everyone from a position of perfect justice.

But clearly Americans don't think this way. Americans think: I am everything and should be. If the goal of philosophy is to get America to consider herself as nothing, in order to be everything (say, a philosophical beacon on the hill), or to speak not for everyone, but, at the very least, for its citizens (if its citizens, that is, demand that America is or become some version of the good city, of Plato's imagined Republic), absolutely no one in America will follow this train of thought, and Cavell's political project, like Thoreau's, is destined to fail (though perhaps protected and preserved by a small coterie of dedicated souls willing to defer, for many more lifetimes to be sure, the conditions necessary for Cavell's words, and Thoreau's for that matter, to be taken up again in future). Thoreau wanted his countrymen to face the founding injustices which created slavery and war, denying at least part of the promise of America which serves to paper over its atrocities. One-hundred and twenty-four years later, Cavell wants his countrymen to do the same, in regards to racism (Civil Rights) and war (in Vietnam). But America will continue to deny its sages and forgo opportunities for redress. Now, a full generation and a half after Cavell's writings in Must We Mean What We Say?, America faces many more setbacks, including Ferguson, MO, and multiple Vietnams (Iraq, Afghanistan, Libya, Syria). Indeed, Cavell can no longer be construed as providing a warning because the warning has come before, unheard then and unheard now. Too late. History is stuck. So what indeed is he doing? 
In the years that Cavell was writing Must We Mean What We Say? Moses appeared in America perhaps a dozen times; and a dozen times an assassin lurked in the shadows. Rather than hearing its prophets, then, and repenting, America refused its mortality altogether, aspired to godlike "awe-inspiring" power, and a kingdom, indivisible, where no angel was fallen. (138)

Jackson's treatment of Cavell is a philosophical enactment not so much of politics, but of love, of self-preservation, and of preserving the other's voice, in particular, the other's voiced desire as mattering, hence preserving one's own voice and ensuring that it, however lost on the multitudes (and to the present moment), still matters also. There is no reason our desires should ever mesh with so-called "political" (i.e., legislative) reality. The collective existence of separate individuals is precisely the idealized form of the good city, i.e., of life in the democratic polis. Collective emancipation is not the goal; rather, it is the emancipation of individuals on a mass scale (one by individual one)-which, in the end, could only be a romantic project, a philosophy suited to spiritual giants, a happy few, and certainly not to the masses. Indeed, no mass redemption is possible, which is another way to say that Cavell's political philosophy, rendered exquisitely here by Jackson, leaves no room for emancipatory politics. The only thing we can share in solidarity is isolation. It is a politics where the hope for redress, redemption, and justice is exclusively spiritual, incapable of making the leap to the material. It is a philosophy designed not to empower the masses but the individual, placing its hopes in the utopian unlikelihood that a good city full of citizens whose words have been thoroughly self-examined are not the ones who ought to rule over others (as in Plato's Republic), but ought to populate the city in its entirety.

In order to be an individual and own one's words, one must face up to one's separateness. Yet it does not follow, or has yet to be established for me convincingly, that claiming one's individuality will, of some political necessity, lead to some type of collective emancipation. But then what have we reduced our collective politics to?brainless masses following dear Leader? Certainly, whatever politics is, emancipation is key, so the real political question is whether one can have a politics of individual emancipation (good enough justice, moving backwards) and collective emancipation 
(not perfect justice, but something like solidarity, which is the continual communal striving towards justice (we can move forward together; we can only move backwards alone)), or if the two remain mutually exclusive, the demarcation of each from the other routinely buttressed not via the existence of libertarian fascists on the one side and totalitarian communists on the other but by the existence of parliamentary democracies which banally promise to take the best from each, compromising both. In Jackson's assessment, Cavell's politics makes a case for occupying this space of convalescence and "forbearance" guaranteed by parliamentary democracies. It is not a challenge of the status quo, but the responsible philosophical survival of its disappointments that is enacted.

Moreover, to hold out on the promise of philosophy is not to be hopeful about the future, which would amount to a romantically trite and exhausted understanding of redemption. Rather, one must face philosophy's continual impotence. We are not to mobilize our political disappointment and make further demands for justice in the world. Rather, we are demanding of ourselves the fortitude and courage to keep holding out on the promise of philosophy, of our words to transform not the outer world of injustice, but the inner world of thought. By so doing, we have conceded a) that we are powerless to change the material conditions of injustice all around us and b) that such acknowledgment is the only form of political redemption or victory philosophy has the business of cultivating. Not demanding that the world change, but demanding that we ourselves change to accommodate a world with such suffering in it with absolutely zero likelihood that the masses will regard such "acts" as redemptive in any way (what we are describing, in fact, are not "acts," but thoughts, which some may regard as the only true acts, but certainly not the majority-hence the risk of being unintelligible, of seeming childish).

So if waging a war on words is first and foremost to wage a war against oneself, why oughtn't we to do it? What is there to lose? Certainly we may lose standing, influence, authority and these are significant traumas, but are, in the end, superficial. If a moral life requires that such a war be waged, what stops even those of us who desire a world with justice and redress in it from moving forward (technically, I should say "backward") in thought? What prevents the activists of the world, for example, from putting down the picket signs to instead retire to Walden pond? 
[T]he promise of rebirth or redemption that the phrase may equally conveythe difference between "wanting this world to stop itself, and wanting all world to end" ... is a difference as infinitesimal as that between comedy and tragedy: just a half step apart; for redemption "presents itself as the dying of the self and hence the ending of the world." This is why we are so reluctant when faced with the promise of change to endure its trials; why even our suffering is so difficult to give up: "But if I change, I am no longer intact; I die to my world. I would rather die." Making matters worse is the fact that we are rarely able to discern whether we have indeed found a new beginning or whether we are only in fact at an end, one reason why Hamlet casts such a long shadow over ... Cavell. It is the grim, unspoken question that darkens his words. (160-161)

The question (To be, or not to be?), of course, concerns suicide for the individual; for we are talking about not the victory of the sage who manages to get through to the polis, but the one unable to do so, who remains, for a lifetime, unintelligible and exiled from others, perhaps even to him/herself. The half-step between comedy and tragedy is the same half-step between insanity and wisdom and there is no good reason-if one undertakes to visit first principles and wage war against oneself and one's own words-that one will come out victorious. Put another way: if the project of individual emancipation can only occur one by individual one, how many deaths without redemption are we willing to risk or tolerate to build the good city? How many are we prepared to send to the nuthouse? More pressingly, how many are we prepared to send not simply to metaphysical extinction, but to physical extinction as well? The promise of parliamentary democracies surely is that we can avoid such needless metaphysical suffering by recycling our disappointments back into the apparatus of state-which means the only victories which count in a democracy are legislative onescertainly not spiritual ones. Martin Luther King Jr. did not demand his followers retire to Walden pond; he had them march on Washington and surely we would rather see our sons and daughters die marching on Washington than die for philosophy.

Which is why I insist that this book, however well-intentioned, leaves us stranded, in a place akin not to Plato's Republic, but Dante's Inferno. The manipular attempt to then pull us out of the ninth circle via the political enactments of Cavellian 
skepticism is unconvincing. Jackson ends his essay on this note of optimism via Whitman:

In scenes of confrontation and acknowledgment [between individuals, of course, not collectives], we join the conversation of justice, clamorous "multitudes" enacting their own existence and also the existence of America each time. "Through me many long dumb voices, / Voices of the interminable generations of prisoners and slaves / Voices of the diseas'd and despairing and of thieves and dwarfs" Cavell hears America singing. (283)

Jackson brings us to the end to be sure, but, perhaps like Hamlet, I do not see a new beginning on the horizon. We have reached the end and nothing in Cavell's philosophy suggests that our humanity will follow; far more likely our viciousness. Unintelligibility, madness, death-these are hardly terms with redemptive currency; add to these "isolation" and "separateness," and where are we? The above noted optimism is clichéd. I hear more resoundingly Jackson's words concluding his second chapter, which perhaps unknowingly leaves the dark vision of Stanley Cavell breached:

It may be that the risk in this way of thinking is that you settle for learning only forbearance, for transforming yourself alone. But then it must still be considered how such transformations can give birth to new worlds ("You are different, what you recognize as problems are different, your world is different": one hopes this is not just a solipsistic delusion) [...]. I claimed that learning how to suffer the world as it is is a necessary condition for changing it [...] as if desire and true needs are born of suffering the world's separation. Cavell's reading of indirectness in Emerson and Wittgenstein understands them as teaching us to learn suffering ("patience and patience"), where despair is the most daunting obstacle in our way, and change requires reconciliation with a world of disappointments, the world we converse with. The paragraph from "Experience" that counsels patience and speaks of the futility of manipular attempts to realize new worlds, the final paragraph of the essay, concludes: 
Never mind the ridicule, never mind the defeat: up again, old heart?-it seems to say-there is victory yet for all justice: and the true romance which the world exists to realize will be the transformation of genius into practical power.

The idea is the bickering sibling of that other great German Idealist of Emerson's time who writes of "that genius which pushes material force to political power." The difference between them is an Emersonian poetics of weakness: the painful knowledge that the revolution is not before us, but always behind us, lost and forgotten, its ambitions in tatters; that change cannot be won at all costs; that you must go on in spite of your failures, because in an imperfect world justice demands of you the discipline, the courage, to fall forever short of its ideal. This is what it means for us to reconcile ourselves to the world's separateness and to allow our interests to be transformed by it-a romance as fraught and profound as any that Hollywood has ever produced. (48-50)

Forbearance must be faced alone. Marx is defeated by Emerson before the so-called political disappointments of twentieth century. Genius is divorced from material and political power. To reconcile ourselves to the world's separateness is precisely to give up on collective emancipation and the goal of the Republic is not to liberate the masses, but to build a city that is good enough to allow us to bear witness to our own philosophical and political ineptitude. That is perhaps a vision of redemption, even an accurate Cavellian vision of redemption. But such enactments of skepticism and separateness are not only a deep compromise with justice, but with politics and collective solidarity altogether. We remain in Hamlet's shadow, in patient forbearance. Can we rest there? 